\title{
Al-Quran Perspective On Architectural Environmentally Friendly in the Aspect of Functions Building
}

\author{
$1^{\text {st }}$ Putri Suryandari ${ }^{1}, 2^{\text {nd }}$ Hamka Hasan ${ }^{2}, 3^{\text {rd }}$ Ahmad Thib Raya ${ }^{3}$, \\ $4^{\text {th }}$ Yusuf Rahman ${ }^{4}, 5^{\text {th }}$ Kusmana $^{5}$ \\ \{putrisyd@gmail.com ${ }^{1}$, hamkahasan@uinjkt.ac.id ${ }^{2}$, ahmad.thib.raya@uinjkt.ac.id ${ }^{3}$, \\ yusuf.rahman@uinjkt.ac.id ${ }^{4}$, kusmana@uinjkt.ac.id ${ }^{5}$ \} \\ Graduate School Sy arif Hiday atullah State Islamic University of Jakarta, Indonesia ${ }^{12345}$
}

\begin{abstract}
The decline in the quality of the global environment has become the most popular problem in this century. One of them is caused by modern architectural planning that is not environmentally friendly. Islam has been explained in the Qur'an QS. Al Baqarah 2: 11-12 that to improve the quality of human life, it has caused damage to the earth. This research is looking for evidence from the verses contained in the Quran regarding environmentally friendly architecture and the causes of destruction for humans on earth by buildings. The results can be proven that in the Al Quran there are verses regarding the development of the function of the building as a place for human activities that are environmentally friendly and the existence of the building can be proven.
\end{abstract}

Keywords: Al-Quran perspective, function building, Al Quran and architecture

\section{Introduction}

Architectural planning in the last few decades, using the concept of Modern Architect ure. Buildings, especially housing, are formed vertically and horizontally with the direction of the International style.

The reason for the emergence of this international style was partly due to the industrial revolution (1800-1900), where factories produced mass products. This mass production forces producers to market their products throughout the world. The uniformity of this material ultimately results in the same building style everywhere, regardless of climatic, geographic, and local cultural factors. This style only considers economic and efficiency factors.

But this trend of international style cannot be sustained, at least for the next 100 years. Many buildings that were planned vertically or horizontally were abandoned, even causing a humanitarian disaster. The architecture of this period turns out to have a sizable contribution to environmental destruction, especially in increasing global temperatures, namely $60 \%$, while housing accounts for $40 \%$ of that number [1].

Seeing the development of architectural practice as written above, it is true that humans are unconsciously the makers of destruction on earth. The practice of developing building planning technology on the pretext of being for human convenience, in a short time has damaged the earth. 
Is lam has been explained in the Quran QS. Al Baqarah (2): 11-12,

"And when it is said to them: 'You must not do damage to the earth'. They replied: "We are the ones making improvements". Remember, they are the ones who do the damage, but they are not aware of it."

Al Quran consists of 4 dimensions, namely writing, reading, meaning, and evidence [2]. Mourice Bucaille admired the contents of the Qur'an and said that the Qur'an is an objective holy book and contains guidelines for the development of modern science. The teaching content is very perfect and does not conflict with the findings of modern science. Interpretation of the ideas contained in the Qur'an, modern science can develop rapidly and play a role in building this world [3].

This study aims to find verses in the Koran that have meaning and evidence about environmentally friendly architecture, especially in aspects of its function as a residence, a place of worship, a building for work and recreation.

The question is how environmentally friendly architecture is written in the Koran, especially environmentally friendly and sustainable for humans and the environment on earth.

\subsection{Problems}

1. As Rahmatan Lil Alamin, how does the Perspective of the Quran explain architecture?

2. What are the facts of the writings contained in the Quran regarding surviving architecture?

\subsection{Aim and Benefit}

\subsubsection{Aim}

a. To get an explanation of the verses of the Al Quran regarding Architecture in the form of writing, reading, and their meaning.

b. Obtain the facts about the explanation of the Koran on general architectural developments.

\subsubsection{Benefits}

a. For academics, as a basic theory in architectural research based on the Al-Quran

b. For practitioners to consider the design process so that it is environmentally friendly.

\section{Theoretical Review}

\subsection{Aspects of Function Buildings in Architecture}

The functional characteristics of a building depend on human activities to fulfill their needs. Humans have 4 main activities in their lives, namely,

a. Residential activities, 
In taking shelter activities, taking shelter from nature and wild animals, humans need a place to live or a house.

b. Worship activities,

In activities to serve oneself to the creator, a place of worship is needed.

c. Work activities to make ends meet,

In the need to carry out work activities and earn a living, a workplace is needed

d. Recreational activities

For the needs to refresh ourselves from daily activities, a place for recreation is needed.

\subsection{Environmentally Friendly in architecture}

The form of architecture continues to develop by the functions, human needs, and existing natural resources. Starting from the form of a dwelling in a cave, in a tree, a stone house, a wooden house, or a house made of iron and steel.

The development in ancient Egypt has the characteristics of giant buildings, for example, carvings in the palace of Pharaoh. The form of architecture continues to develop in the direction of Classical, Byzantine, Romanesque, Gothic, Ren aissance, Baroque, Neoclassicism, Art Nouveau, Neo-Gothic Architecture, Art Deco Architecture, Modernist Style to Postmodernism which is increasingly clawing the sky.

In 1987, the World Commission on Environment and Development (WCED), also known as the Brundtland Commission, discussed a central theme, namely „Our Common Future“, also known as the Brundtland Report. This report describes the possibility of a new era of economic growth that maintains and expands the existing environmental resources, at which time the built environment is beginning to be disrupted by modernization. So then in this Brundtland report, sustainable development is formulated where one of the derivatives of the concept is, Eco-Friendly Architecture.

Friendly building concept environment (eco-friendly architecture) there are 4 (four) groupings/sections that are necessary attention, namely, green open space, a sanitation system supporting savings and availability of clean water, efficient use of energy, and utilization of building material technology that utilizes local natural resources.

\subsection{The Qur'an and its 4-dimensional characteristics}

As explained by KH Fahmi Basya [2], Al Quran has the characteristics of 4 dimensions, namely 1 . writing, 2. reading, 3. meaning, and 4. facts.

Table 1. 4 Dimensional in the Quran.

\begin{tabular}{c|l|l}
\hline \multicolumn{3}{c}{ 4 Dimensions in the Qur'an } \\
\hline $\mathbf{1 .}$ & $\begin{array}{l}\text { Writing } \\
\text { In QS 2: 2 it is explained that the writings } \\
\text { in the Qur'an do not doubt it. Where } \\
\text { people can benefit from it in the form of } \\
\text { knowledge and good deeds. }\end{array}$ & $\begin{array}{l}\text { QS 2. This book (Al-Qur'an) } \\
\text { does not doubt him; a guide for } \\
\text { explained that the writings of the Koran } \\
\text { are immutable and imperishable. It is }\end{array}$ \\
$\begin{array}{l}\text { written on the guarded tablets of Allah, } \\
\text { which he cannot corrupt in any way. }\end{array}$ & \\
\hline $\mathbf{2}$ & Reading, & \\
\hline
\end{tabular}




\begin{tabular}{|c|c|c|}
\hline & $\begin{array}{l}\text { The word qur'ān, which already exists in } \\
\text { the Islamic holy book itself } \\
\text { comes from the verb qara'a - "to read," } \\
\text { "to read" - but there may also be some } \\
\text { connection with the Syriac qeryana, "to } \\
\text { read," used for reading scriptures during } \\
\text { church services. The Qur'an, compiled in } \\
\text { its early form of Classical Arabic, is } \\
\text { traditionally believed to be a literal } \\
\text { transcript of God's letter and an earthly } \\
\text { reproduction of an uncreated and eternal } \\
\text { heavenly original, according to the } \\
\text { general view referred to in the Qur'an } \\
\text { itself [3]. }\end{array}$ & $\begin{array}{l}\text { QS 9-111. Indeed, Allah buys } \\
\text { from the believers, both } \\
\text { themselves and their possessions } \\
\text { by giving them heaven. They } \\
\text { fight in Allah's way; so that they } \\
\text { either kill or are killed, (as) the } \\
\text { true promise of Allah in the } \\
\text { Torah, the Bible, and the Koran. } \\
\text { And who can keep his promises } \\
\text { more than Allah? So be happy } \\
\text { with the buying and selling that } \\
\text { you have done, and this is a great } \\
\text { victory. }\end{array}$ \\
\hline 3 & $\begin{array}{l}\text { Meaning } \\
\text { In QS 35: } 33 \text { it is said that the Quran has } \\
\text { the best meaning and explanation and the } \\
\text { most accurate interpretation, although } \\
\text { disbelievers will present arguments for } \\
\text { debate. There are many interpretations of } \\
\text { the verses of the Quran that can only be } \\
\text { explained through research and the } \\
\text { process of understanding technology and } \\
\text { development. }\end{array}$ & $\begin{array}{l}\text { QS 35: } 33 \\
\text { (They will find) heaven 'Adn, } \\
\text { they enter into it, in it, they are } \\
\text { adorned with bracelets of gold } \\
\text { and pearls, and their garments in } \\
\text { it are silk }\end{array}$ \\
\hline 4 & $\begin{array}{l}\text { Fact } \\
\text { The explanation of reading in the Koran } \\
\text { may not have been obtained in the past, } \\
\text { but it is known in the present after much } \\
\text { evidence has been found in the modern } \\
\text { century. }\end{array}$ & $\begin{array}{l}\text { QS 6:67 } \\
\text { Every message (brought by the } \\
\text { Prophet) has (a time) of } \\
\text { occurrence and one day you will } \\
\text { know (the fact). }\end{array}$ \\
\hline
\end{tabular}

So that all the writings contained in the Al Quran can be proven by facts, this fact can explain that the AlQuran is a science directly from Allah SWT, to reveal the secrets of the universe, including architecture.

\section{Research Methods}

This research is qualitative research which is library research which uses books and other literature as the main object. This type of research is qualitative, namely research that produces information in the form of notes and descriptive data contained in the text under study.

With qualitative research, descriptive analysis is necessary. The descriptive analysis method provides a clear, objective, systematic, analytical, and critical description and information regarding the science of architecture contained in the Qur'an. A qualitative approach that is based on the initial steps taken by collecting the required data, then classification and description are carried out. 


\section{Results and Discussion}

There are no searches regarding the verses of the Qur'an that write about architecture, but in the process of forming a place for human life on earth, it begins with verses about the creation of the heavens and the earth, as well as the supporting elements in it.

When finally a universe was complete for human needs, then humans were created. The creation of a place to live for humans has indeed been provided through several processes of space formation, namely the empty universe, the sun and the solar system, the earth (air, land, water, plants, and animals) as found in QS An Naziat 27-33.

\subsection{Al-Quran Perspective On the Aspect of Functions in Architectural}

\subsubsection{The perspective of the Quran regarding a resident}

Table 2. A Place to human Live in Al Quran.

\begin{tabular}{|c|c|c|}
\hline Writing and Reading & Meaning & Fact \\
\hline $\begin{array}{l}\text { QS Al Hijr 15: } 82 \\
\text { and they carve the houses out of } \\
\text { the rock, (which are inhabited) } \\
\text { with a sense of security. } \\
\text { Q.S. An-Nahl 16: 80 } \\
\text { And Allah made houses for } \\
\text { you, as dwellings and He made } \\
\text { for you houses (tents) from the } \\
\text { skins of the cattle that you feel } \\
\text { light (carry) them, when you } \\
\text { travel and when you live and } \\
\text { (He makes them also) from } \\
\text { sheep's hair, camel hair, and } \\
\text { goat hair, household items, and } \\
\text { fun until a (certain) time. }\end{array}$ & $\begin{array}{l}\text { In ancient times, mentioned } \\
\text { in the days of the Add } \\
\text { people, houses and } \\
\text { buildings were made in } \\
\text { mountains and caves } \\
\text { In Al-Ghazin's Tafseer, it is } \\
\text { stated that there are houses } \\
\text { that cannot be moved } \\
\text { (permanently) such as } \\
\text { houses made of stone and } \\
\text { two houses that can be } \\
\text { carried anywhere like tents } \\
\text { made of livestock skin[4]. }\end{array}$ & \\
\hline
\end{tabular}

\subsubsection{The perspective of the Quran regarding places of worship}

In realizing the existence of God, humans will perform worship activities (worship). Al Quran has given instructions, regarding places of worship.

Table 3. A Place of Worship in Al Quran.

\begin{tabular}{c|c|c}
\hline Writing and Reading & Meaning & Fact \\
\hline QS Ali Imran 3: 96. & & \\
\hline
\end{tabular}




\begin{tabular}{|c|c|c|}
\hline $\begin{array}{l}\text { Indeed, the first house } \\
\text { (worship) that was built for } \\
\text { humans, was (Baitullah) } \\
\text { which was in Bakkah (Mecca) } \\
\text { which was blessed and } \\
\text { became a guide for all nature. } \\
\text { QS Yunus 10: 87. } \\
\text { And We revealed to Moses } \\
\text { and his brother, "Take some } \\
\text { houses in Egypt for your } \\
\text { people (dwellings) and make } \\
\text { your houses a place of } \\
\text { worship and pray and cheer } \\
\text { up the believers." }\end{array}$ & $\begin{array}{l}\text { It can be explained here that } \\
\text { the Kaaba in Mecca was the } \\
\text { first Muslim place of } \\
\text { worship, which could serve } \\
\text { as an example of a place of } \\
\text { worship for all Muslims } \\
\text { During the Covid } 19 \\
\text { pandemic, it has been proven } \\
\text { that all houses have become } \\
\text { places of worship for } \\
\text { Muslims, because of the } \\
\text { prohibition on gathering and } \\
\text { having to maintain distance in } \\
\text { public places, as well as in } \\
\text { places of worship. }\end{array}$ & Hell \\
\hline
\end{tabular}

Through the two verses above, it can be explained that the place of worship for Muslims can be done outside the home, as a gathering place for all people, and can be carried out in the home, to worship with family.

\subsubsection{The perspective of the Quran regarding a place to work or to be creative}

Al Quran explains how the presence of human works in the form of a magnificent building at the time of the previous prophets, has appeared.

Table 4. A Place to Work or to be creative in Al Quran

\begin{tabular}{l|l|}
\hline \multicolumn{1}{c|}{ Writing and Reading } & \multicolumn{1}{|c}{ Meaning } \\
\hline QS Saba 34: 13 & $\begin{array}{l}\text { That the Prophet Solomon } \\
\text { could command the genie } \\
\text { army, at that time to build } \\
\text { tall and magnificent }\end{array}$ \\
$\begin{array}{l}\text { Shey (the jinn) worked fomon according to what } \\
\text { he wanted, including } \\
\text { (making) tall buildings, } \\
\text { tall buildings and there are } \\
\text { statues, plates (large) like } \\
\text { ponds, and fixed pots (above } \\
\text { the stove). Work, O family } \\
\text { form of large plates and pots } \\
\text { like there are stoves. } \\
\text { Allah). And very few of My } \\
\text { servants are grateful. }\end{array}$ & $\begin{array}{l}\text { Borobudur Temple by KH } \\
\text { Fahmi Basya in his 30th } \\
\text { research.[5] }\end{array}$ \\
\hline
\end{tabular}

Currently, many buildings with shiny floors made of marble, granite, and glass have been made using modern technology. Descriptions in the Qur'an regarding the work of these tall buildings and magnificent palaces have been achieved in the past. So that the Al Quran has inspired humans to make these works, now and in the future. 


\subsubsection{The perspective of the Quran regarding a place to work or be creative}

If we try to describe it, the limitations of human senses and understanding will not be able to describe the true condition of heaven. However, through various verses in the Koran and several hadiths, Allah SWT has described the pleasures of heaven which can be used as a reference to the concept of a garden, although it will not be comparable to the pleasures of heaven in the hereafter. If we follow this concept, balance, harmony, and sustainability of nature and the environment on earth will be achieved [6].

Table 5. A Place for recreation in Al Quran.

\begin{tabular}{|c|c|c|}
\hline Writing and Reading & Meaning & Fact \\
\hline $\begin{array}{l}\text { QS Ar-Rad 13: 35 } \\
\text { The parable of heaven which } \\
\text { was promised to those who fear } \\
\text { (is like a garden), flowing under } \\
\text { it rivers; always fruitful and } \\
\text { shady. That is the place of the } \\
\text { end for those who fear; while } \\
\text { the final place for those who } \\
\text { deny God is hell. } \\
\text { QS al-Baqarah 2: } 25 \\
\text { "And convey the happy news to } \\
\text { those who believe and do good } \\
\text { deeds, that they are provided } \\
\text { with the heavens that flow the } \\
\text { rivers in it. Whenever they are } \\
\text { given sustenance of fruits in } \\
\text { these heavens, they say, "This is } \\
\text { what was given to us before". } \\
\text { They are given similar fruits } \\
\text { and for them, some wives are } \\
\text { holy and they are eternal in } \\
\text { them " }\end{array}$ & $\begin{array}{l}\text { Referring to the } \\
\text { repeated descriptions of } \\
\text { the existence of surges, } \\
\text { it is a place filled with } \\
\text { plants and flowing } \\
\text { underneath rivers, } \\
\text { illustrating that the ideal } \\
\text { garden, or a place of } \\
\text { good and harmonious } \\
\text { recreation, is that there } \\
\text { are pools of flowing } \\
\text { water } \\
\text { The physical } \\
\text { characteristics } \\
\text { mentioned in the Koran } \\
\text { are beautiful, shady, } \\
\text { large areas, easy access, } \\
\text { and common areas } \\
\text { (public), all of which } \\
\text { are things that are very } \\
\text { well applied in planning } \\
\text { and designing an an } \\
\text { Islamic garden. }\end{array}$ & \\
\hline
\end{tabular}

\subsection{The Quranic perspective on tall buildings as the cause of destruction}

Several verses in the Al Quran explain, a nation which has tall buildings, will end with the destruction of its people.

\subsubsection{The Ad}

As told to the inhabitants of Iram in Surat Al-Fajr verses 7-8, the Iram nation had succeeded in mastering technology and had high buildings that had never been built in other countries.

This verse explains the existence of tall buildings (skyscrapers) that were carried out by the population at that time past which is ultimately enshrined in the verses of the Quran. The 
building above already has lighting technology, namely natural lighting obtained from the sun as its energy source which is then used to facilitate human activities in it.

Table 6.

\begin{tabular}{l|l|l}
\hline \multicolumn{1}{c|}{ Writing and Reading } & \multicolumn{1}{|c}{ Meaning } \\
\hline QS Al-Fajr: 7-8, 12 & $\begin{array}{l}\text { And that is the country of } \\
\text { Aad, the Prophet Hud' } \\
\text { (peace be upon him) } \\
\text { which Allah has destroyed } \\
\text { with a very cold and } \\
\text { strong wind, IWith] Iram - who had } \\
\text { lofty pillars, }\end{array}$ \\
$\begin{array}{l}\text { 8.The likes of whom had } \\
\text { never been created in the } \\
\text { land? }\end{array}$ & $\begin{array}{l}\text { Their intelligence (in } \\
\text { high-tech buildings), } \\
\text { seems to have made them } \\
\text { disbelievers and negligent } \\
\text { so that Allah became } \\
\text { angry with them by } \\
\text { eliminating all nations } \\
\text { the corruption } \\
\text { from the face of the earth. }\end{array}$ & $\begin{array}{l}\text { The archaeologist who managed to } \\
\text { find the ruins of the City of Iram was in 1990.[7] }\end{array}$ \\
\hline
\end{tabular}

\subsubsection{The Faraoh}

Pharaoh to reach the sky where Lord Moses lived, had ordered the engineers of his era to build the highest pyramid in the world until the pyramid of Giza was built.

Table 7.

\begin{tabular}{l|l|l}
\hline Writing and Reading & \multicolumn{1}{|c|}{ Meaning } & Fact \\
\hline QS 28: 38 & $\begin{array}{l}\text { It means then make for } \\
\text { me (Pharaoh) a tall } \\
\text { building so that I will see } \\
\text { Him (Lord Moses) and } \\
\text { stand before Him, in his } \\
\text { And Pharaoh said, "Onfession (Moses) who } \\
\text { eminent ones, I have not } \\
\text { known you to have a god } \\
\text { other than me. Then ignite } \\
\text { for me, O Haman, [a fire] } \\
\text { upon the clay and make } \\
\text { for me a tower that I may } \\
\text { look at the God of Moses. God } \\
\text { And indeed, I do think he } \\
\text { he is an Apostle. }\end{array}$ \\
\begin{tabular}{l} 
is among the liars." \\
\hline
\end{tabular}
\end{tabular}


As we all know Pharaoh was the most renegade man, so he claimed to be the God of his people. When the Egyptian population is getting fanatical about their kufr. Their hostility and denial of Allah's messenger (Musa) fueled the desire to kill and oppress him and those who followed him. It was then that Allah sent his army to destroy Pharaoh and his people [8]

According to American and French scientists, Professor Gilles Hug and Professor Barsoum, a model of stone making is burned underwood, then the wood is heated to form almost normal hard rock. This scientist als o mentioned, actually Pharaoh was very good at chemistry and managing clay [9].

\subsection{Green Architecture in the Perspective of the Qur'an}

In the explanation of the functional characteristics of buildings in the Qur'an, there are several provisions for surviving architecture, referring to the repeated explanations in ("Surat Al-Araf: 56-58") regarding existence, land, plants, wind, and also rain. So the spatial dimension for architecture should not only discuss the need for space and human comfort. The space for movement and the comfort of other elements outside of humans will give good to humans and the universe.

Heaven is described as a place that is very comfortable for humans, that is, there are rivers, fertile soil, various fruits, and fresh air. Not a closed space with artificial airs and lifeless artificial objects.

So that it can be formulated as follows:

1. Architecture must conform to environmental geographic factors

2. Architecture must be by the culture of the population

3. Architecture must use environmentally sensitive materials

4. Architecture must be harmonious and take into account the air, water, and plants around it

5. Tall buildings must consider environment-sensitive factors

So far, the provisions above have started to be made compulsory for all buildings in the world, especially in the agreement on Sustainable Development. The principle of preserving nature, being environmentally friendly and all its derivatives that are being promoted intensively in the present, have been written in the Al Quran. The principle of green building which encourages humans to protect the earth in line with the Islamic concept, which guides so that buildings are in harmony with nature, have properties that exist in nature, are not wasteful of energy and do not damage nature

\section{Conclusion}

The perspective of the Koran in the field of architecture is not written explicitly about architecture, but rather explains the characteristics of functions in buildings and materials. The development of architecture as a forum for human activity from time to time has been written in the Koran, through writing, reading, meaning, and facts.

In the aspect of building functions, there are 4 categories in Architecture, Environmentally Friendly Architecture in the Al Quran explains, 


\subsection{Residential Aspects}

In Surat An-Nahl and Al Hijr, it is explained that a residence is built with materials and uses existing technology around the environment. Buildings are adapted to the patterns of human activities in living

\subsection{Aspects of the workplace or to be creative}

In the QS Saba and Al Mukmin, it is explained that the workplace or creating creations in building, intellectual (intelligence) can be applied optimally. Can use high technology, but still environmentally friendly. The buildings that have survived until now are proven to use simple materials found around the environment.

\subsection{Aspects of places of worship}

The place of worship is explained that it can be made inside and outside the house. In surah Ali Imran, it is clear that places of worship for Muslims should be made on a large scale, so that they can be used by many people. Whereas in Surah Yunus it says that, our houses must have a place for worship.

\subsection{Aspects of recreation areas}

As in Surah Al Baqarah and Al Araad, recreation areas are described as supposed to be like gardens of heaven, contained in flowing water, trees, animals, blooming flowers, and fresh air. These natural factors can create a balance in the environment on earth

The use of the material is described starting from the use of natural materials in the form of rocks, trees, and animal skins, to iron and technological as sistance.

The perspective of the Koran on architecture is proven by the findings of facts about the legacy of the building.

Al Quran has warned, how the destruction and destruction of a nation will occur when tall buildings begin to appear on the face of the earth if they do not pay attention to space for movement and the comfort of other elements outside of humans. 


\section{References}

[1] Stephen M. Wheeler, Planning for Sustainability,. Roudledge, 2004.

[2] K. F. Basya, Al Quran 4 Dimensi Tulisan,bacaan,makna,fakta, 1st ed. Republika, Penerbit, 2007.

[3] H. Ringgren and N. Sinai, "Qur'an Sacred Text," Encyclopedia Britania, 2007. [Online]. Available: https://www.britannica.com/topic/Quran. [Accessed: 22-Jun-2020].

[4] Alauddin Ali Bin Muhammad, Tafsir Ghazin, 1st ed. (Bairut: Dar Al-kutub Al-alamiah, 1995.

[5] KH Fahmi Basya, Borobudur \& Peninggalan Nabi Sulaiman, 2nd ed. Zaituna, 2012.

[6] M. Jannah, W. Q. Mugnisjah, and A. Gunawan, "Kajian Konsep Taman Islam Berdasarkan Al Quran Dan Hadits," El-HARAKAH (TERAKREDITASI), vol. 17, no. 1, p. 1, 2015.

[7] “THECITY OF IRAM.”[Online]. Available: https://sites.google.com/site/whatisinthebook/home/histrory -inside-quran-the-city-of-iram. [Accessed: 03-Sep-2020].

[8] Rusman Siregar, "Kisah Nabi Musa dan Kebinasaan Firaun," kalam.sindonews.com, 2019. [Online]. Available: https://kalam.sindonews.com/berita/1406135/70/kisah-nabi-musa-dankebinasaan-firaun. [Accessed: 16-Jun-2020].

[9] Agung Sasongko, "Pembuatan Piramida Menurut Alquran," Republika.co.id, 2019. [Online]. Available: https://republika.co.id/berita/pme5ep313/pembuatan-piramida-menurut-alquran. [Accessed: 16-Jun-2020]. 